\title{
Obogaćivanje glazbenog doživljaja i izražaja djece rane i predškolske dobi tradicijskim stvaralaštvom
}

Blaženka Bačlija Sušić*

blazenkabs@gmail.com

Nikolina Fišer**

ninolina.f@gmail.com
UDK: 78-053.4

398.8-053.4

Izvorni znanstveni rad / Original scientific paper Primljeno: 30. prosinca 2015. Prihvaćeno: 29. veljače 2016.

Predmet ovog akcijskog istraživanja je poticanje i obogaćivanje glazbenog stvaralaštva djece rane i predškolske dobi tradicijskim stvaralaštvom. Istraživanje se bavilo pitanjem mogućnosti unapređenja odgojno-obrazovnog procesa djece rane i predškolske dobi poticanjem i obogaćivanjem glazbenog doživljaja elementima tradicijskog stvaralaštva. Cilj istraživanja bio je ispitati koji su elementi, sadržaji i aktivnosti vezani uz glazbeno tradicijsko stvaralaštvo prihvatljivi $i$ zanimljivi djeci u trećoj i četvrtoj godini života te potiču li oni u njima glazbeni doživljaj i interes za glazbenim aktivnostima općenito.

Dobiveni rezultati provedenog istraživanja ukazuju da djeca rane i predškolske dobi pokazuju velik interes za glazbene aktivnosti koje uključuju istraživanje zvukova različitih tradicijskih instrumenata kao i za njihovu upotrebu pri izvodenju glazbe. Svakodnevno dopunjavanje odgojno-obrazovnog procesa tradicijskom glazbom putem brojalica, dječjih pjesmica i igara s pjevanjem uz upotrebu tradicijskih instrumenata, potiče djetetovu slobodu i spontanost, stvaralačku maštu $i$ kreativnost te proširuje njihov emotivni doživljaj glazbe.

Ključne riječi: akcijsko istraživanje, glazbeno stvaralaštvo, glazbeni doživljaj, djeca rane i predškolske dobi, tradicijsko stvaralaštvo.

\footnotetext{
* Dr. sc. Blaženka Bačlija Sušić, prof. mentor, GU Elly Bašić, Mlinarska cesta 25, HR-10000 Zagreb.

**Nikolina Fišer, mag. praesc. educ., odgojiteljica u Dječjem vrtiću »Špansko«, Špansko 11, HR10000 Zagreb.
} 


\section{Uvod}

U današnje vrijeme prevladava mišljenje da moderna društva mogu napredovati jedino ako su inovativna, što podrazumijeva poticanje kreativnog djelovanja pojedinaca. Na taj način može se doći do mnoštva novih ideja, pogleda, sinteza, novih otkrića te time postići i značajniji društveni napredak. ${ }^{1}$

Kada su u pitanju kultura i umjetnost, važnim se smatra očuvanje umjetničke tradicije. Pod time se podrazumijeva da napredak čovjeka i društva ne ovisi samo o novostvorenim umjetničkim djelima, nego i o njihovoj vezi s vlastitom tradicijom. Upravo je glazba jedan najprirodnijih medija koji djeci predškolske dobi omogućuje susret $\mathrm{s}$ tradicijom, odnosno tradicijskim stvaralaštvom koje se generacijama prenosilo $s$ koljena na koljeno. Tijekom tog procesa prenošenja i bogaćenja dječjeg odrastanja, došlo je do novih i vrijednih dječjih stvaralačkih tvorevina koje su svoju vrijednost dokazale upravo očuvanjem kroz vrijeme.

Potreba za kreativnim izrazom jedna je od prirodnih čovjekovih potreba koja se prepoznaje već kod djece rane i predškolske dobi. Kako bi se ta potreba realizirala i kako bi dijete uspjelo iskazati svoje stvaralačke potencijale, važno je poticajno i kreativno okruženje koje će podržati svaki djetetov stvaralački impuls. Na važnost poticajnog okruženja u djetetovoj ranoj dobi, osobito do treće godine života, ukazuju brojna istraživanja ${ }^{2}$ koja ističu da je aktivnost mozga $u$ tom periodu dva puta veća od one u odraslih osoba. Upravo su roditelji ti koji kod djeteta uočavaju znakove kreativnosti. ${ }^{3} \mathrm{~S}$ obzirom da takvo okruženje pruža djetetu osjećaj ugode, mira i sigurnosti te omogućuje razvoj dječjih sposobnosti i kreativnosti, potrebno ga je što ranije obogaćivati glazbenim doživljajima. Rezultat ugodnih glazbenih aktivnosti »bit će zadovoljno, nesputano, radosno dijete čije glazbene mogućnosti u svakom trenu dolaze do izražaja«, osobito sposobnosti slobodnog glazbenog izražavanja. ${ }^{4}$ Utvrđeno je da kreativnost (mjerena testovima divergentnog mišljenja) opada kada djeca krenu u vrtić, oko dobi od pet ili šest godina. ${ }^{5}$ To nadalje navodi na pitanje je

\footnotetext{
${ }^{1}$ Usp. Ante FULGOSI, Rea FULGOSI MASNJAK, Psihologija stvaralačkog mišljenja. Od introspekcije do asocijacionizma, Suvremena psihologija, 8 (2005) 1, 63-95.

${ }^{2}$ Usp. Sue ROBSON, Sue SMEDLEY, Education in Early Childhood. First things first, London, David Fulton publishers, 1996, 71-153; David HOWE i dr., Attachment Theory, Child Maltreatment and Family Support. A Practice and Assessment Mode, New York, Palgrave, 1999; Loris MALAGUZZI, History, ideas, and basic philosophy. An interview with Lella Gandini, u: C. EDWARDS, L. GANDINI, G. FORMAN (ur.), The Hundred Languages of Children. The Reggio Emilia Approach - Advanced Reflections, Greenwich, CT, Ablex Publishing Corporation, 1998; Alison GOPNIK, Andrew N. MELTZOFF, Patricia K. KUHL, Znanstvenik u kolijevci. Što nam rano učenje kazuje o umu, Zagreb, Educa, 2003.

${ }^{3}$ Usp. Jasna CVETKOVIĆ-LAY, Vid PEČJAK, Možeš $i$ drugačije, Zagreb, Alineja - CPDD Bistrić, 2004.

${ }^{4}$ Usp. Ljerka MARIĆ, Ljiljana GORAN, Zapjevajmo radosno, Zagreb, Golden marketing, 2013, 13.

${ }^{5}$ Usp. Karen S. MEADOR, Emerging rainbows. A review of the literature on creativity, Journal for the Education of the Gifted, 15 (1992) 2, 163-81.
} 
li to prirodna posljedica djetetova sazrijevanja i ograničenja koje postavljaju socijalne norme ili djetetova iskustva i doživljaji u vrtiću na neki način izazivaju opadanje djetetove kreativnosti.

Premda se o dječjem glazbenom stvaralaštvu danas puno govori i piše, $u$ praksi uglavnom susrećemo reproduktivne, a puno rjeđe stvaralačke aktivnosti.

»Povijesno gledano, barem od Scola cantorum, pa sve do danas, kroz nastavu smo umjesto kreativnih, odgojili reproduktivne tipove... « ${ }^{6}$

Dječja zvukovna istraživanja i stvaranja kao dio vrtićke svakodnevnice, često su neshvaćena i zanemarena, a upravo su ona osnova budućih glazbenih aktivnosti. Prve djetetove zvukovne improvizacije nastaju djetetovim sviranjem na svemu oko sebe, a rezultat su njegova spontanog stvaralačkog izraza, njegove slobode, mašte i kreativnosti. Pri tome je nerijetko zadivljujuća djetetova uživljenost u sam stvaralački proces te njegov doživljaj glazbe, bez obzira na produkt stvaranja. Budući da mala djeca nemaju uvijek potrebne vještine za izradu kreativnog proizvoda, primjerenije je staviti naglasak na kreativni proces nego na produkt. ${ }^{7}$

»Kreativnost postaje vidljiva kada odrasli veću pozornost usmjeravaju na djetetove kognitivne procese nego na postignute rezultate u različitim područjima djelovanja i razumijevanja. ${ }^{8}$

Bogatstvo emocionalnog doživljaja od neprocjenjive je vrijednosti za djetetov kako emocionalni i kognitivni, tako i za njegov cjeloviti razvoj. Stvaranje nečeg novog, originalnog, svojeg, kod djeteta razvija osjećaj sreće i uspjeha, što osobito pozitivno utječe na njegov osjećaj vrijednosti, postignuća te samopouzdanja. ${ }^{9}$

Dječje tradicijsko stvaralaštvo također je izraz potrebe za kreativnošću i razonodom, a ima sve bitne elemente predajne kulture. Riječ je o »bogatom, raznovrsnom i autentičnom stvaralaštvu « ${ }^{10} \mathrm{u}$ koje pripadaju predaje i motivi koje su za djecu stvarali odrasli (uspavanke) te kreacije nastale kao proizvod dječje mašte i nadahnuća (brojalice, rugalice, igre, imitacije i dr.). Uz navedene oblike, u bogato i raznovrsno dječje stvaralaštvo koje pripada nematerijalnoj tradicijskoj kulturi ubrajaju se i igre prstima, brzalice, ritmičke igre, dječje pjesme, prigodne pjesme vezane uz vjerske i svjetovne običaje, dječje igre i sl., dok u materijalnu tradicijsku kulturu dječjeg folklora pripadaju dječji instrumenti,

\footnotetext{
${ }^{6}$ Elly BAŠIĆ, Improvizacija kao kreativni čin, Umjetnost i dijete, 5 (1973) 26, 44-69, 48.

7 Usp. Deborah W. TEGANO, James D. MORAN, Janet K. SAWYERS, Creativity in Early Childhood Classrooms (NEA Early Childhood Education Series), West Haven, CT, National Education Association, 1991.

8 Malaguzzi, nav. dj., 49-97.

${ }^{9}$ Usp. Blaženka BAČLIJA SUŠIĆ, Akcijsko istraživanje improvizacije u individualnoj nastavi klavira, Tonovi. Časopis glazbenih i plesnih pedagoga, 60 (2012) 2, 25-58.

${ }^{10}$ Goran KNEŽEVIĆ, Naše kolo veliko, Zagreb, Ethno, 1993, 7.
} 
prigodni rekviziti i oprema, narodna nošnja i frizure, likovno stvaralaštvo i razna druga umijeća i materijalne tvorbe.

$\mathrm{Na} z$ značenje i dobrobit glazbe te važnost poticanja djetetova glazbenog razvoja i stvaralaštva radi njegova cjelovitog razvoja ukazuju, kako suvremeni $\mathrm{Na}$ cionalni kurikulum za rani i predškolski odgoj i obrazovanje, ${ }^{11}$ tako i smjernice istaknute u Programskom usmjerenju odgoja i obrazovanja predškolske djece, ${ }^{12}$ koji naglasak stavlja na poticanje glazbenih doživljaja, izražavanja i stvaranja u različitim odgojnim situacijama.

Uz navedeno, jedno od tri osnovna potpodručja u kojima dijete stječe kompetencije, a na kojem se temelji struktura predškolskog kurikuluma, uključuje djetetovu spoznaju svijeta oko sebe koja uz prirodno i šire društveno okružje uključuje i kulturnu baštinu i održivi razvoj. ${ }^{13}$

Upravo bi vrtićko okruženje, uz djetetovo svakodnevno spontano usvajanje značajki kulturne sredine kojoj pripada, trebalo od djetetove rane dobi poticati i provoditi različite aktivnosti koje će doprinijeti očuvanju tradicijskih vrijednosti. Stoga smo se, kako radi poticanja dječjega glazbenog stvaralaštva, tako i radi upoznavanja tradicijskog stvaralaštva kod djece rane i predškolske dobi, odlučili na provođenje ovog akcijskog istraživanja.

\section{Metodološki okvir istraživanja}

\subsection{Problem i ciljevi istraživanja}

Provedeno istraživanje bavilo se pitanjem načina poticanja i obogaćivanja glazbenog stvaralaštva te glazbenog doživljaja i izražaja djece rane i predškolske dobi elementima tradicijskog stvaralaštva. Kako to ističu predstavnici tzv. životno-teorijskog pristupa osnovni cilj provođenja akcijskog istraživanja je rješavanje specifičnih problema i unapređivanje prakse.

»Kroz razmjenu iskustava u praksi, kritikom i učenjem jedni od drugih, vjerujemo da ćemo razviti nove oblike obrazovne teorije koja je direktno ukorijenjena u ljudskim iskustvima i životnoj stvarnosti.« $1^{14}$

\footnotetext{
${ }^{11}$ Usp. MINISTARSTVA PROSVJETE I KULTURE REPUBLIKE HRVATSKE, Programsko usmjerenje odgoja i obrazovanja predškolske djece, Glasnik Ministarstva prosvjete $i$ kulture Republike Hrvatske, 10. lipnja 1991.

${ }^{12}$ Usp. MINISTARSTVO ZNANOSTI OBRAZOVANJA I ŠPORTA REPUBLIKE HRVATSKE, Nacionalni kurikulum za rani i predškolski odgoj i obrazovanje, Zagreb, http://public.mzos.hr/ Default.aspx?art=13571 (20.07.2015).

${ }^{13}$ Usp. MINISTARSTVO ZNANOSTI OBRAZOVANJA I ŠPORTA REPUBLIKE HRVATSKE, Nacionalni okvirni kurikulum za predškolski odgoj $i$ obrazovanje te opće obvezno $i$ srednjoškolsko obrazovanje, Zagreb, www.azoo.hr/images/stories/dokumenti/Nacionalni_ okvirni_kurikulum.pdf (20.07.2015).

${ }^{14}$ Jean McNIFF, Jack WHITEHEAD, Action Research. Principles and Practice, London, Rout-
} 
Uz temeljni cilj unapređenja odgojno-obrazovne prakse djece rane i predškolske elementima tradicijskog i glazbenog stvaralaštva, postavljaju se sljedeći ciljevi:

1. Odabrati i integrirati elemente tradicijskog stvaralaštva u odgojno-obrazovni proces;

2. Istražiti koji su glazbeni elementi, sadržaji i aktivnosti dječjeg tradicijskog stvaralaštva prihvatljivi i zanimljivi djeci u trećoj i četvrtoj godini života te im omogućuju zadovoljenje interesa za sviranjem, pjevanjem i kretanjem;

3. Učiniti odgojno-obrazovni proces raznovrsnijim poticanjem djetetove slobode, stvaralačke mašte, fantazije i emotivnog doživljaja glazbenim aktivnostima;

4. Poticati i podržavati djecu u aktivnostima glazbenog stvaranja tijekom svakodnevnog odgojno-obrazovnog procesa (kreativno izražavanje zvukom i pokretom);

5. »Vratiti djeci dječje «; $;^{15}$

6. Usavršiti stručna znanja i kompetencije odgojitelja kao istraživača i refleksivnog praktičara;

7. Utvrditi dobrobiti, promjene i efekte u odnosu na djetetov glazbeni te osobni razvoj na početku i na kraju provođenja istraživanja.

\subsection{Metode istraživanja}

S obzirom na specifičnost problemskog pitanja koji se odnosi na načine poticanja i bogaćenja glazbenog doživljaja djece rane i predškolske dobi elementima tradicijskog stvaralaštva, odlučili smo se za akcijsko istraživanje koje unutar paradigme kvalitativnih istraživanja čini sustavno, participativno istraživanje u prirodnim uvjetima, odnosno u svakodnevnom odgojno-obrazovnom procesu, uz primjenu metode studije slučaja kao oblika izvještaja u kvalitativnom istraživanju.

\subsection{Postupci i instrumenti za prikupljanje podataka}

Tijekom istraživanja pratilo se i dokumentiralo sve vezano uz implementaciju plana istraživanja, pri čemu su se koristili različiti postupci i instrumenti za prikupljanje podataka radi tumačenja učinaka akcije. Prikupljanje, proučavanje i interpretiranje dokumentacije ujedno je istraživački i refleksivan proces koji

\footnotetext{
ledgefalmer, ${ }^{2} 2002,147$.

${ }^{15}$ Goran KNEŽEVIĆ, Sad se vidi, sad se zna, Zagreb, Ethno, 2012, 7.
} 
uključuje sam sadržaj i proces učenja te je od neprocjenjive važnosti u provođenju svake etape istraživanja. ${ }^{16}$

Jedan od postupaka korištenih u istraživanju bilo je sustavno promatranje, kojim se istraživači izravno upoznaju s pojavama koje proučavaju jer se promatra stvarna pedagoška situacija, onakva kakva ona zaista jest. ${ }^{17} \mathrm{~S}$ obzirom na postojeće tehnike sustavnog promatranja, u istraživanju su korištena oba načina: promatranje uz pomoć tehničkih pomagala (kamera i fotoaparat) i izravno, odnosno tzv. »sudjelujuće« promatranje prema kojem osoba koja promatra pedagošku situaciju i sama sudjeluje u njoj. Dok je dobivena video dokumentacija omogućavala cjelovitiji uvid u zabilježene dijelove odgojno-obrazovnog procesa i samog konteksta istraživanja, tzv. »sudjelujućim promatranjem« dobiveno je mnogo više istinitijih i pouzdanijih podataka s obzirom da je promatrač stalno u okolini koju promatra. ${ }^{18}$

Istraživačkim, odnosno refleksivnim dnevnikom pratio se i detaljno bilježio tijek akcijskog istraživanja kao i promišljanja, zapažanja, nastalih promjena te novih ideja i zaključaka, sukladno kojima se usmjeravala daljnja akcija.

Na kraju istraživanja, u svibnju pedagoške godine 2014./15., provedeno je i skupno intervjuiranje djece. Takav način prikupljanja podataka "prirodniji je te ga djeca percipiraju kao manje zastrašujućeg od individualnog intervjua« ${ }^{19}$

S obzirom da akcijsko istraživanje pripada paradigmi kvalitativnih istraživanja, nakon prikupljanja dovoljnog broja podataka o problemu kojim se bavi ovo istraživanje, izvršeno je kodiranje te triangulacija prikupljenih podataka.

\subsection{Sudionici istraživanja}

Istraživanje se provodilo tijekom dvije pedagoške godine, točnije od rujna 2013. do lipnja 2014. godine te od rujna 2014. do lipnja 2015. godine. Provedeno je u Dječjem vrtiću »Špansko« u Zagrebu, u odgojnoj skupini »Bubamare«. U istraživanje je bilo uključeno 24 djece, 8 djevojčica i 16 dječaka u dobi od treće do četvrte godine života.

\footnotetext{
${ }^{16}$ Usp. Edita SLUNJSKI, Kurikulum ranog odgoja, Zagreb, Školska knjiga, 2011, 86.

${ }^{17}$ Usp. Vladimir MUŽIĆ, Metodologija pedagoškog istraživanja, Sarajevo, Svjetlost, ${ }^{6} 1986,211$.

${ }^{18}$ Usp. Mužić, nav. dj., 245.

${ }^{19}$ Louis CHOEN, Lawrence MANION, Keith MORRISON, Metode istraživanja u obrazovanju, Jastrebarsko, Naklada Slap, 2007, 287.
} 


\section{Tijek istraživanja}

\subsection{Prvi krug istraživanja}

Prvi krug istraživanja trajao je jednu pedagošku godinu (2013./14.), a sam proces provođenja glazbenih aktivnosti započeo je obogaćivanjem i proširenjem postojećeg glazbenog centra u sobi dnevnog boravka tradicijskim instrumentima. S obzirom da su se u stvaranje Etno kutka uključili i roditelji, djeca su uz roditelje obogaćivala svoje spoznaje o prikupljenim materijalima koje su pronalazili kod baka i djedova na selu, na moru ili na sajmovima, gdje su ih kupovali s roditeljima. Sukladno izvoru, prikupljeni instrumenti podijeljeni su u tri skupine: biljke i plodovi, instrumenti iz okuženja, tj. kućanstva te instrumenti koji su kupljeni.

»Kvalitetno i poticajno okruženje sadržava visok obrazovni potencijal, s obzirom na to da djeca uče aktivno (istražujući, čineći) te surađujući s drugom djecom i odraslima. $\aleph^{20}$

Nastojalo se da glazbeni centar postane mjesto gdje će djeca rane dobi živjeti i učiti neposredno istražujući svijet oko sebe te tijekom interakcije sa svojom socijalnom i materijalnom okolinom. S obzirom da je sloboda temelj kreativnosti, odnosno $»$ kreativnost je derivat slobode ${ }^{21}$ vodilo se računa da djeca uz dovoljno materijala mogu slobodno istraživati i igrati se zvukovima, tonovima i melodijama kroz individualno i zajedničko stvaranje. Prema okvirno postavljenim cijevima, u prvom krugu akcijskog istraživanja, nakon prikupljanja potrebnih sredstava i obogaćivanja glazbenog centra, svakodnevno smo promatrali reakcije i interes djece. Djeca su na aktivan način, istraživanjem oblika, teksture i dr., upoznavala novoprikupljene instrumente, pri čemu su neki od njih imali potrebu i okusiti ih.

Osobito je bio zanimljiv istraživački poriv dječaka F. M. koji je nekoliko dana aktivnim osluškivanjem i istraživanjem zvukova dobivenih trešnjom šuškalice od osušene tikvice (šef), pokušavao na sve načine otkriti što se nalazi unutra. Unatoč negodovanju i upozorenjima odgojiteljice, dječak ju je jednoga dana ipak uspio razbiti.

»On je imao potrebu, osim zvuka, istražiti što taj zvuk proizvodi. Tim glazbeno-istraživačkim činom omogućio je sebi i drugoj djeci da spoznaju što se to nalazi unutar tikvice što proizvodi zvuk, odnosno kako izgledaju koštice i sama unutrašnjost tikvice« (Refleksivni dnevnik, 14. studenoga 2013.).

Uvidjevši značenje tog spoznajno-istraživačkog čina, kako za dječaka tako i za drugu djecu, odgojiteljica je adekvatno reagirala na nastalu situaciju.

\footnotetext{
${ }^{20}$ Edita SLUNJSKI, Dječji vrtić. Zajednica koja uči, Zagreb, Spektar media, 2008, 21.

${ }^{21}$ Bašić, nav. dj., 49.
} 
Aktivnosti istraživanja i stvaranja zvukova bile su spontane i individualne, a spontanost je, kako to ističe Elly Bašić, "početna i neophodna faza kreativnosti «. ${ }^{22} \mathrm{Uz}$ to, aktivnosti su bile popraćene osjećajem ugode i zadovoljstva, a posebno ushićenje i radost nastali su kada su djeca počela stvarati kratke improvizacije na instrumentima. Razina na kojoj djeca istražuju različite kombinacije zvukova na instrumentima, čime najčešće nastaju slučajni zvukovi, prva je razina improvizacije. ${ }^{23} \mathrm{~S}$ obzirom da je u početku odgojiteljica vodila i podržavala taj proces, djeca su stalno usmjeravala pogled prema njoj tražeći potvrdu svojeg stvaralaštva. Kasnije su djeca postala sve samostalnija, te su aktivnosti uz minimalnu podršku odraslih, prerastale u zajedničku igru u kojoj su stvarali jedni za druge.

U početku je dolazilo do sukoba kada je dvoje ili više djece željelo istodobno svirati na istom instrumentu, dok su se kasnije djeca uspijevala dogovoriti oko podjele instrumenata i formiranja malih orkestara.

»To je bilo vrlo frustrirajuće djeci i meni kao odgojiteljici. Tijekom jedne takve situacije, u procesu bila je prisutna i pedagoginja, moj kritički prijatelj. Skrenula mi je pozornost na to da su takve situacije odlične za konstruktivno rješavanje sukoba u kojima su svi na dobitku, a djeca postupno usvajaju socijalne vještine i postaju kompetentnija « (Refleksivni dnevnik, 20. studenoga 2013.).

Posebnu dobrobit od navedenih aktivnosti imao je dječak D. D. koji već drugu pedagošku godinu uopće nije komunicirao s odgojiteljicom, a vrlo rijetko i s djecom. Najprije je samostalno istraživao instrumente kada u centru nije bilo puno djece, a kasnije je, nudeći instrumente drugoj djeci kako bi zajednički svirali, počeo s njima i neverbalno komunicirati.

»Tijekom glazbene aktivnosti pjevanja brojalice Eci, peci, pec i sviranja na instrumentima, čula sam novi glas u sobi. Bio je to glas D. D. On je zajedno $s$ djevojčicom I. i dječacima N. i J. Š. svirao, a potom i zapjevao. Dječak N. ga je začuđeno pogledao, a I. se nasmijala i predložila da otpjevaju opet, što je D. D. prihvatio. Od početnoga grča na njegovu licu, polako se pojavljivao osmijeh kad uspio se opustiti« (Refleksivni dnevnik, 4. veljače 2014.).

Nakon pjevanja brojalice, dječak je polako počeo i govoriti što se ubrzo proširilo na svakodnevnu komunikaciju, kako s djecom, tako i s odraslima u vrtiću.

\subsubsection{Obogaćivanje odgojno-obrazovnog procesa aktivnostima dječjeg tradicijskog stvaralaštva}

Nakon aktivnosti istraživanja i upoznavanja prikupljenih instrumenata i stvaranja prvih malih improvizacija, aktivnosti su bile usmjerene na odabir elemenata dječjeg tradicijskog stvaralaštva kojima će se obogatiti glazbene aktivnosti. $\mathrm{S}$ obzirom da se radilo o djeci koja su još prolazila period prilagodbe, igre

\footnotetext{
${ }^{22}$ Isto, 51.

${ }^{23}$ Usp. John KRATUS, Growing with Improvisation, Music Educators Journal, 78 (2005) 4, 36-40.
} 
s prstićima, cupkalice i tapšalice činile su se kao izvrstan odabir za ostvarenje bolje interakcije te toplijeg i sigurnijeg odnosa s odgojiteljicom. U početku su djeca odlično reagirala na ove aktivnosti, međutim, na svaku pojavu novih instrumenata u glazbenom centru sve manje su imala potrebu za individualnim kontaktom s odgojiteljicom te su više pozornosti obraćala na svoje vršnjake.

Poseban interes djeca su pokazivala za aktivnosti koje su bile obogaćene ritmičkim govorom, odnosno brojalicama. One pripadaju među najstarija i najvrednija sačuvana blaga dječjega govornog i glazbenog stvaralaštva. Nazivaju je »zvukovnom slikom poezije.$^{24}$

»Brojalica u svojoj osnovi nije tek puko prebrojavanje sudionika buduće igre ili pak određivanje jednoga za početak igre, već je to pravo dječje stvaralaštvo temeljeno na zvučnoj igri ritmiziranog teksta (riječi i slogova), koje se sve do naših dana prenosilo isključivo usmenim putem. $\aleph^{25}$

Djeca su u početku više pozornosti pridavala brojalicama sa smislom (Eci, peci, pec; Medo; Pliva patka preko Save), dok su kasnije u svojim glazbenim aktivnostima sve više koristila brojalice koje sadrže iracionalne riječi, poput Eniki, beniki; Enci, benci i En, ten, tini.

Zahvaljujući poticaju djeda koji je svog unuka naučio brojalicu iz svojeg djetinjstva, došlo je, obogaćena je kako aktivnosti tako i sam istraživački proces. Djeca su prihvatila novu brojalicu, koju je potom, na prijedlog djeteta J. Š., na loncima najprije odsviralo nekoliko djece zajedno, a potom naizmjence:

$$
\begin{aligned}
& \text { Zuli, zuli, patka stala, } \\
& \text { Sigurno je blizu bala, } \\
& \text { iza nje se preko blega, } \\
& \text { mala pačat gega. }
\end{aligned}
$$

Aktivnosti su se svakodnevno obogaćivale novim idejama i spontanim načinima izvođenja. Tako je spontano došlo do djetetova sinkretičkog izraza kroz sviranje, pjesmu i ples. Takav sinkretički pristup glazbi potiče oslobađanje kreativne energije i omogućuje prirodan cjeloviti razvoj djeteta.

»Ako djetetu omogućimo da se izražava na onom području na kojem je sposobnije, ono će biti spontanije i dobiti na samopouzdanju. ${ }^{26}$

Uz brojalice i pjesme, do dječjeg sinkretičkog izraza došlo je i prilikom izvođenja igara s pjevanjem koje su jedna od najznačajnijih narodnih umotvorina namijenjenih djeci, a koje same po sebi uključuju pjesmu i ples. »Želja za ritmičkim pokretom i plesnim izričajem prirođena je svakom ljudskom biću«, ${ }^{27}$

\footnotetext{
${ }^{24}$ Milica BUINAC, Književnost i dječje stvaralaštvo u riječi, u: Livija KROFLIN i dr. (ur.), Dijete $i$ kreativnost, Zagreb, Globus, 1987, 209-237, 220.

${ }^{25}$ Ksenija BURIĆ-SARAPA, Eci, peci, pec, Zagreb, IBIS grafika, 2003, 3.

${ }^{26}$ Bašić, nav. dj., 52.

${ }^{27}$ Dijana ŠKRBINA, Art terapija i kreativnost, Zagreb, Veble commerce, 2013, 179.
} 
pa je tako i nezaobilazan odgovor na slušanje i doživljavanje glazbe djeca rane i predškolske dobi.

Nov izazov bio je izbor dječje igre s pjevanjem iz bogatog repertoara tradicijske ostavštine, a koje će biti prilagođene mogućnostima i interesima djece $\mathrm{u}$ trećoj godini. Ringe, ringe, raja (Šestine, Zagrebačko prigorje) pokazala se najomiljenijom dječjom igrom s pjevanjem koju djeca rado izvode kako s odgajateljicom, tako i samostalno na način da se prime za ruke, formiraju kolo, plešu i pjevaju. Najprivlačniji dio te igre je pokret u čučanj, koji najviše raduje djecu te s nestrpljenjem očekuju taj trenutak. Kako bi se riješio problem formiranja kruga pri uključivanju većeg broja djecu u igru, uključena je dječja igra s pjevanjem Ide vlak teretnjak (Siće, Slavonija). Ova aktivnost koja se odvija u formaciji kolone, pokazala se odličnom za okupljanje djece i spontano formiranje kola. Kao omiljena, pokazala se i dječja igra s pjevanjem Pilići (Donja Dubrava, Međimurje) koja se izvodi na tepihu, sjedeći ili ležeći te kuckajući o pod.

»Primijetila sam da poneka djeca, osim prstima, sviraju i dlanovima. Takav način sviranja unijeli smo kao nov element u igru, odnosno kada pjevaju pilići, sviramo prstićima, a kada koke, sviramo dlanovima« (Refleksivni dnevnik, ožujak 2014.).

Tradicijske dječje igre i aktivnosti proširile su se i izvan granica odgojne

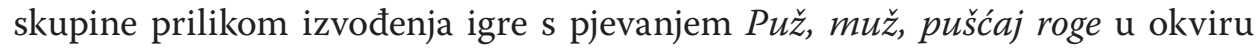
projekta u kojem su sudjelovala djeca iz susjedne vrtićke skupine »Ribice«. Osim toga, redovita provedba navedenih dječjih igara s pjevanjem, rezultirala je osmišljavanjem malog scenskog prikaza, koji su djeca izvela pred ostalom djecom i odgojiteljima prigodom proslave Maskenbala te pred roditeljima na završnoj svečanosti. Uvidom u prikupljene materijale utvrđena je velika vrijednost igara s pjevanjem, kako radi daljnjeg poticanja i motiviranja djeca tako i radi pozitivnog utjecaja na razvoj njihovih tjelesnih, glazbenih i društvenih vrijednosti.

\subsubsection{Interpretacija - analiza provedenog prvog kruga istraživanja}

Tijekom prvoga kruga istraživanja građena je refleksivna praksa i to »refleksijom $u$ akciji te refleksijom na akciju. Cilj toga je pogled unatrag i razmatranje novih dimenzija sljedeće akcije. ${ }^{28}$

$\mathrm{Na}$ temelju promatranja i analize osobnog djelovanja, procesom samorefleksije, refleksije i metakognicije, usmjeravane su daljnje aktivnosti prema postavljenom problemu i cilju istraživanja, kao i radi unapređenja odgojnoobrazovne prakse.

Uz spoznaju o važnosti samog procesa samostalnog istraživanja i otkrivanja za dijete, odgojiteljica je zaključila da je birane aktivnosti potrebno prilagoditi

${ }^{28}$ Mirjana ŠAGUD, Odgajatelj kao refleksivni praktičar, Petrinja, Visoka učiteljska škola, 2006, 18-19. 
djetetovim individualnim afinitetima, potrebama, željama, mogućnostima i sposobnostima, a radi dodatnog poticanja djetetove kreativnost i njegova stvaralačkog potencijala.

Posredno uključivanje roditelja te baka i djedova, oplemenilo je ovo istraživanje te omogućilo djeci da budu aktivni sukreatori samog procesa istraživanja i izvan vrtićkog okruženja, što nije bilo predviđeno okvirnim planom. Navedene aktivnosti, kako samostalnog, tako i zajedničkog otkrivanja i stvaranja pretvorile su se djeci u najzanimljiviju igru. Predviđene jutarnje aktivnosti protegnule su se na cjelodnevnu aktivnost u kojoj su djeca kroz emotivni doživljaj samostalno dolazila do novih otkrića i spoznaja. Stoga se i sam proces sustavnog promatranja pretvorio u cjelodnevni proces, koji je čak i prešao granice odgojne skupine »Bubamare«, uključivši povremeno i drugu djecu iz njihova okruženja.

Brojne spoznaje dobivene tijekom provođenja 1. kruga akcijskog istraživanja značajno se utjecale na odgojiteljeve stavove koji su se odrazili na daljnju akciju. Spoznavši neizmjernu vrijednost samostalnog otkrivanja sadržaja razbijene tikvice, kako za dječaka F. M. tako i za drugu djecu, odgojiteljica je u daljnjim aktivnostima na isti način prilazila takvim situacijama. Uz to, uz dodatne sugestije pedagoginje, svojeg kritičkog prijatelja, vezane uz sukobe oko sviranja na istom instrumentu, spoznala je značenje takvih situacija za konstruktivno rješavanje sukoba, što se reflektiralo na daljnje kvalitetnije socijalne interakcije i kompetencije kod djece koje potiču na zajedništvo u istraživanju i spontanom stvaranju. Odgojiteljica je nadalje uočila da je razdoblje nakon popodnevnog odmora pa do odlaska kući, s obzirom na manji broj djece, izuzetno pogodno za slobodnije istraživanje i stvaranje, kako za djecu tako i za nju kao promatrača. U takvom opuštenijem i mirnijem ozračju može se kvalitetnije pratiti proces, osluškivati dječje misli i osjećaje, pratiti njihovu neverbalnu komunikaciju te sukladno tome promišljati, obogaćivati i usmjeravati daljnje aktivnosti akcijskoga istraživanja. Pri tome je još jasnije uočena dobrobit navedenih aktivnosti za djecu slabijih socijalnih kompetencija. Osobito je značajna spoznaja o dobrobiti navedenih glazbenih aktivnosti za dječaka s teškoćama u razvoju govora koji je uključenjem u navedene aktivnosti nakon nekog vremena počeo najprije neverbalno, a zatim i verbalno komunicirati s djecom i odgojiteljicom.

Kako improviziranjem na tradicijskim instrumentima uz brojalice za koje su djeca pokazivala najveći interes, tako i izvođenjem igara s pjevanjem i drugih oblika nematerijalne tradicijske baštine (igre rukama, cupkalice i tapšalice i sl.), spontano je došlo do poticanja dječjeg glazbenog stvaralaštva putem djetetova sinkretičkoga izraza. Znatno manji interes uočen je za dječje pjesme, koje su uglavnom pjevane i korištene u aktivnostima na inicijativu odgojiteljice, a puno manje u slobodnoj i spontanoj dječjoj igri, što je potvrđeno i dodatnim istraživanjem putem intervjua s djecom. Uz navedeno, uočena je i potreba kako za revizijom ponuđenih instrumenata u glazbenom centru, tako i za njegovim obogaćivanjem novim materijalima. 
Da bi se potvrdile navedene spoznaje do kojih se došlo tijekom provedenog prvog kruga akcijskog istraživanja, dobiveni podatci su kodirani, odnosno šifrirani tako da su razvrstani u kategorije s obzirom na promatrane aktivnosti koje su se, sukladno nepredviđenom tijeku samog istraživanja, mijenjale i nadopunjavale. Podatci su najprije kategorizirani na materijalni (instrumenti koji su prikupljeni u glazbeni centar) i nematerijalni aspekt (brojalice, igre rukama, cupkalice, tapšalice, dječje pjesme i dr.) tradicijske kulturne baštine, odnosno tradicijskog stvaralaštva. Ustanovljene su i posebne kategorije s obzirom na spontano nastale aktivnosti istraživanja i upoznavanja različitih oblika tradicijske baštine koje su se odvijale u glazbenom centru. Spoznalo se da je u daljnjem istraživanju naglasak potrebno staviti kako na promišljanje pojedinih aktivnosti sukladno interesima djece, tako i samog konteksta provođenja koje će dodatno podržati njihov interes i biti prilagođen njihovoj dobi i mogućnostima, a radi jačeg izričaja njihove kreativnosti i stvaralačkog potencijala. $S$ tim $\mathrm{u}$ vezi, dodana je posebnu kategoriju u koju će se svrstati podatke vezane uz provođenje stvaralačkih aktivnosti, koje su logično slijedile nakon što su djeca upoznala i istražila postojeće materijalne oblike tradicijske baštine te su im se dodatno približili i oblici nematerijalne tradicijske baštine.

Tako je, nakon planiranja i provedene akcije u prvom krugu akcijskoga istraživanja te promatranja i analize dobivenih materijala, daljnja akcija usmjerena na stvaralačke aktivnosti. Osim toga, s obzirom na velik interes koji je u prvom krugu uočen u suradnji s roditeljima, djecom i odgojiteljima iz druge skupine, izmijenjen je okvirno postavljen plana širenjem aktivnosti i uključivanjem novih sudionika u sam proces. Uz zajednički dogovor i sugestiju kritičkog prijatelja i pokazani interes kolega i roditelja, zaključeno je da je sam proces akcijskog istraživanja i njegovih rezultata potrebno dodatno približiti roditeljima i ostalim sudionicima odgojno-obrazovnog procesa, kako na razini skupine, tako i na razini same ustanove pa i šire, a radi dodatnog obogaćivanja odgojnoobrazovnog procesa.

\subsection{Drugi krug istraživanja}

Novi krug akcijskog istraživanja koji se odvijao tijekom pedagoške godine 2014./15., započeo je aktivnostima koje su se temeljile na spoznajama prethodnoga akcijskog kruga kao i na aktivnostima prethodno postavljenog okvirnoga plana.

$\mathrm{S}$ tim u vezi, nastojalo se kako roditeljima putem kutića za roditelje te roditeljskih sastanaka, tako odgojiteljima i kolegama putem prezentacija na sastancima i stručnim aktivima, pružiti dodatni uvid u sam proces istraživanja $i$ stečene spoznaje. Uz to, ostvareno je i sudjelovanje u programu »Djeca i mladi u očuvanju kulturnog naslijeđa«, koji je održan od 24. do 29. rujna 2014. godine na prostoru Vrapčanske aleje u Zagrebu, u okviru tradicionalne kulturno-zabavne, edukativne i sportske manifestacije »Susedgradske jeseni«. Upravo je to bio po- 
ticaj za daljnje prikupljanje dječjih tradicijskih instrumenata, dječjih igračaka i za izradu rekvizita za obogaćivanje dječjih igara s pjevanjem, čemu su doprinijeli i roditelji iz drugih vrtićkih skupina. Nakon toga, a sukladno zaključcima prvog kruga, uklonjeni su instrumenti koji djeci nisu bili zanimljivi i koji su rijetko korišteni te je centar nadopunjen novim instrumentima. Radi daljnjeg unapređenja same aktivnosti istraživanja, kao i dodatnog širenja stvaralačkih aktivnosti vezanih uz tradicijsko stvaralaštvo na druge odgojne skupine u vrtiću, održana je edukativna radionica »Tradicijski instrumenti« pod vodstvom umjetnika Filipa Martinića. Tom prigodom djeca su prepoznala brojne instrumente iz svoga glazbenog centra i upoznala neke nove instrumente. Uz to, ostvarena je i međunarodna suradnja u europskom projektu Comenius+ u okviru kojeg su razmijenjena iskustva vezana uz tradicijsko stvaralaštvo $\mathrm{s}$ odgojiteljicama iz čeških vrtića koje su tijekom gostovanja u odgojnoj skupini »Bubamare« bile oduševljene spontanim dječjim stvaranjem u ugodnu i veselu ozračju.

\subsubsection{Poticanje dječjeg glazbenog stvaralaštva}

S obzirom na spoznaje do kojih se došlo tijekom prvoga kruga akcijskog istraživanja, aktivnosti drugog kruga usmjerene su prema individualnim potrebama, željama, interesima, mogućnostima i sposobnostima djece, a radi daljnjeg poticanja i podupiranja procesa kreativnog stvaranja elementima dječjeg tradicijskog stvaralaštva. Polazeći od stajališta o osobitom značenju djetetova slobodnog i kreativnog glazbenog izraza kroz improvizaciju koja utječe kako na djetetov glazbeni, tako i na njegov cjeloviti razvoj (razvoj kreativnog mišljenja, stvaralački pristup životnim izazovima, razvoju samosvijesti, sigurnosti i samopouzdanja i sl.), u drugom krugu je stavljen naglasak na brojalice koje djeca svakodnevno koriste u igri, ali uz poticaj na mijenjanje postojećih riječi.

Djeca su pri tome uživala u glasovnim kreacijama i svojoj sposobnosti stvaranja uz pratnju na instrumentu, pri čemu je, kao i u svim dosadašnjim stvaralačkim aktivnostima, naglasak bio na samom procesu, a ne na produktu stvaranja.

Kao rezultat djetetova stvaralačkog izraza, nastale su sljedeće brojalice:

Eci, peci, pec,

U rupu skoči zec,

Krava ne zna gdje je zec,

Pa kaže mu, ти, тиии.

Djevojčica B. $(4,2)$

Ide patka preko rijeke,

Nosi pismo na vrh glave,

Pazi da te ne ogrebe.

Djevojčica I. $(4,2)$
Eci, peci, pec,

Ti si mali zec,

U rupu skoči Iva,

U rupu skoči zec.

Dječak J. K. $(3,8)$

En, den, dore,

Duboko je more,

More je daleko,

Pa ja pijem mlijeko.

Dječak J. Š. $(4,2)$ 
Uz navedene aktivnosti, s obzirom na zaključke dobivene $u$ prvom krugu akcijskog istraživanja te radi poticanja većeg interesa za dječje pjesmice, dječju se svakodnevnicu nastojalo obogatiti dječjim pjesmama koje su bile prilagođene godišnjim dobima i blagdanima. Djeca su u početku pjevala melodiju i tekst pjesama uz odgojiteljicu, a kasnije su, uz poticaj, počela samostalno varirati melodiju, tekst i ritam stvarajući tako male melodijsko-ritamske improvizacije i otkrivajući pritom neslućene mogućnosti svojega glasa, slobode mašte i kreativnosti, bez obzira na produkt stvaranja. Najprihvaćenija dječja pjesmica koja je svakodnevno izvođena uz ples i sviranje Hopa, cupa, skoči, doživjela je brojne preinake, pa su tako nastale improvizacije na stihove djeci najdraže strofe.

Ho-pa, cu-pa, skoči da ti vi-dim oči,

Da ti vi-dim, o-či-ce, ma-le-na dje-voj-či-ce.

Potom se nadovezao dječak N. J. $(3,3)$ :

Kru-ška, ja-bu-ka, šlji-va ve-li mi-li Ja-kov,

to je vo-će sla-tko, je-o bi ga sva-tko.

Varirajući riječi pjesmice Cin, can, cvrgudan nastali su sljedeći stihovi:

Dječak J. Š. (4): Zin zan zi-gu-dan.

Dječak N. $(3,8)$ : Din don din-do-dan.

Dječak J. K. (3,6): Tin ton tin-ton-tan.

Dječak F. M. (3,4): Bum bum bum-bum-bum.

Djeca su nekoliko mjeseci tražila da im se reproducira pjesmica iščekujući pri tome dio na koji su stvarala svoje stihove, dok su uz ostatak pjesmice plesala ili svirala na instrumentima. Navedene stvaralačke aktivnosti, pokazatelj su djetetova aktivnog izraza i doživljaja glazbe koji, ne samo da potiče djetetov interes za navedene aktivnosti, nego i jača te oblikuje dječju maštu, pozitivno utječe na njihovo raspoloženje, potiče socijalne odnose i navike kulturnog ophođenja te razvija pozitivnu sliku o sebi i jača njihovo samopouzdanje. Dječje igre s pjevanjem, za koje su djeca pokazala velik interes u prvom krugu istraživanja, u drugom krugu su se također izvodile na nove načine kako bi se dodatno potaknuo njihov interes i stvaralački potencijal. Primjerice, dječja igra Pilići izvodila se tako da su djeca bila podijeljena u skupine koka i pilića. $\mathrm{Na}$ znak dirigenta (odgojiteljice ili djeteta) djeca su naizmjenično, poput razgovora, pjevala određeni dio teksta pjesmice u određenoj dinamici.

Dječja igra s pjevanjem Ide vlak teretnjak provodila se varirajući tempo izvođenja pjesmice pjevanjem i kretanjem. Kako bi djeca dodatno osvijestila pojam kruga, odgojiteljica je potaknula djecu da nacrtaju krug i da se međusobno promatranje tijekom plesa.

Variranje tempa i dinamike u poznatim igrama, omogućilo je djeci nove doživljaje i obogatilo načine njihove svakodnevne igre, koja se sve više odvijala spontano, bez poticaja i sudjelovanja odgojiteljice. 


\subsubsection{Interpretacija - analiza provedenog drugog kruga istraživanja}

U drugom krugu akcijskog istraživanja pomno su birane aktivnosti prilagođene djetetovim potrebama, željama, interesima, mogućnostima i sposobnostima, a radi dodatnog poticanja djetetove kreativnosti i njegova stvaralačkog potencijala. Novi poticaji rezultirali su improvizacijama postojećih brojalica i pjesmica, pri čemu je pjesmom, plesom i sviranjem došlo do djetetova sinkretičkog izraza na tradicijskim instrumentima. Pri tome je uočeno da je tehnička pomagala (kamera, fotoaparat i sl.) potrebno koristiti tako da se ne ometa sam proces jedinstvenih i neponovljivih stvaralačkih aktivnosti, a radi podupiranja metarazine učenja i stvaranja. U svemu tome, najvažniji je bio sam proces stvaranja koji je praćen osjećajem ushita i ponosa za onoga koji stvara te osjećajem sreće i zahvalnosti onoga za kojeg se stvara. Promatranjem i analizom audio i video zapisa uočeno je da djeca uz samostalno stvaranje potiču i druge na stvaralačke aktivnosti obogaćivanja odgojno-obrazovnog procesa tradicijskim stvaralaštvom. Uz to, u zajedničkom pregledavanju snimki djeca su izrazila svoje osjećaje sreće, zadovoljstva, vlastite vrijednosti i samopouzdanja što ih je dodatno potaknulo i motiviralo na daljnje aktivnosti. Zahvaljujući suradnji među skupinama, djeca su obogatila svoje glazbeno iskustvo upoznavanjem novih instrumenata iz bogate hrvatske tradicijske baštine. Osim toga, ostvaren je i postavljeni cilj drugoga kruga akcijskoga istraživanja koji se temeljio na uključivanju novih sudionika u sam proces, kako na lokalnoj tako i na međunarodnoj razini.

Nadalje je uočeno da su tijekom provedenih aktivnosti dječaci skloniji motorički aktivnijim igrama i bučnijim aktivnostima, dok su se djevojčice, kojih je bilo znatno manje u skupini, više odazivale sudjelovanju u dječjim igrama s pjevanjem te su ih same često spontano poticale. Osim toga, uočeno je da navedene aktivnosti djeca uglavnom imaju potrebu izvoditi u zatvorenom prostoru, što je razumljivo s obzirom na to da danas djeca puno manje vremena provode u slobodnoj igri na zraku.

Implementiranjem improvizacije kao stvaralačkog čina u glazbene aktivnosti utvrđeno je da se i aktivnosti koje su se djeci pokazale manje privlačne i za koje su djeca u početku pokazivala manji interes, kao primjerice pjevanje pjesmica, mogu osmisliti na nov način i tako ih približiti djeci i pretvoriti u njima izazovnu i poticajnu stvaralačku aktivnost. Na taj način, uz osjećaj stvaranja nečeg originalnog, novog, svojeg, djeca su dobila na samopouzdanju i vrijednosti, a odgojitelj je pri tome mogao bolje spoznati njihove skrivene potencijale i prema tome ciljano poticati i usmjeravati njihov daljnji razvoj. Osim toga, odgojitelj je spoznao veliko značenje socijalne interakcije kojem su doprinijele kako aktivnosti unutar matične skupine, tako i šire, na razini cijelog vrtića te uključivanje roditelja.

Budući da uz kvalitativne podatke kvantitativni upotpunjuju sliku o istraživanom problemu, kako bi se dodatno potvrdile te dopunile istraživačke spoznaje, dobivenim se kategorijama pridodalo i rezultate provedenog intervjua s djecom. 


\subsubsection{Analiza skupnog intervjua sudionika akcijskog istraživanja}

Na kraju istraživanja, tijekom svibnja 2015. godine, provedeno je skupno intervjuiranje djece, sudionika navedenog akcijskog istraživanja. Vođenje intervjua provodilo se tijekom jutarnjih aktivnosti u sobi dnevnog boravka, a u njemu su u nekoliko skupina sudjelovali svi sudionici istraživanja.

Rezultati intervjua potvrdili su prethodna zapažanja i zaključke: 40,9 \% ispitanika, odgovorilo je da vole sva tri oblika glazbenih aktivnosti (sviranje, pjevanje, plesanje), od čega je njih 13,6 \% izjavilo da vole svirati, a isto toliko djece je odgovorilo da vole plesati. Nadalje, 13,6 \% djece izjavilo je da vole pjevati i svirati, njih $9 \%$ da vole pjevati i plesati, a 4,5\% voli kombinaciju sviranja i plesanja. Samo 4,5 \% djece navedene glazbene aktivnosti doživljava kao igru. Među tri najdraža instrumenta, 40,9\% djece navodi rifljaču, lončiće 31,8 \% i stepaču 27,2 $\%$, dok su potkova, daščica s kuhačom i frula manje atraktivni instrumenti za sviranje. Kao najdraže brojalice 36,3 \% ispitanika navodi brojalice En, ten tore i Eci, peci pec, dok brojalicu En, ten tini navode u najmanjem postotku (13,6 \%), što je iznenađujuće s obzirom na to da se ta brojalica najčešće izvodila.

Rezultati intervjua potvrdili su uočeni manji interes djece za dječje pjesme. Čak 36,3\% djece se tijekom intervjua nije moglo sjetiti niti jedne dječje pjesme. Ipak, na poticaj odgojiteljice i prijedlog pjevanih pjesmica, $31,8 \%$ posto djece navodi pjesmu Hopa, cupa, skoči kao najdražu.

Kao najdraže igre s pjevanjem, djeca navode igru Ide vlak teretnjak $(68,1 \%)$ te Pilići, koju su djeca prozvala Oni naši pilići $(45,4 \%$ ). U najmanjem postotku navode igru Puž, muž, pušćaj roge van, koja je bila aktualna samo tijekom projekta Puž u skupini.

Dobivena kvantitativna analizu dodatno je potkrijepila i potvrdila prethodne spoznaje o stajalištima i interesu djece prema pojedinim aspektima materijalne i nematerijalne tradicijske baštine koji su korišteni u istraživanju i bili posebne kategorije u koje su svrstavani prikupljeni podatci. Stoga su dobiveni rezultati integrirani u postojeće kategorije i potom je izvršena triangulacija prikupljenih podataka.

S obzirom na to da je ovo istraživanje koncipirano kao akcijsko, čiji je cilj spoznavanje i mijenjanje postojeće pedagoške prakse, uz samostalnu analizu nužna je i zajednička analiza prikupljenih podataka. Stoga je odgojiteljica najprije sama, a potom s pedagogom, svojim kritičkim prijateljem, i s kolegicom koja je sudjelovala u radionici upoznavanja tradicijskih instrumenata, razmotrila i analizirala dobivene podatke. Uspoređivanjem različitih izvora podataka, odnosno kategorija u koje su podaci razvrstavani, dodatno su potvrđene i obogaćene navedene spoznaje i tako je dobiven cjelovit uvid u provedeno istraživanje. 


\section{Refleksija i rasprava}

Provedenim akcijskim istraživanjem kao oblikom kvalitativnog istraživanja holistički se pristupilo istraživanju problema u kojem se, zbog složenosti, nije stavljao naglasak na rezultat, već prioritetno na sam proces. Kroz stečena iskustva i spoznaje odgojitelj je došao do brojnih novih saznanja koja su, kako tijekom istraživanja tako i kasnije, utjecale na transformaciju njegovih stavova i odgojno-obrazovnih postupaka u njegovoj daljnjoj odgojnoj praksi.

Istraživanje koje se u početku temeljilo na upoznavanju i istraživanju različitih oblika materijalne i nematerijalne tradicijske baštine koja, kako je zaključeno, i danas privlači interes i pažnju djece, spontano je dovelo i do poticanja djetetova stvaralačkog potencijala kroz glazbeni i sinkretički cjeloviti izraz i doživljaj glazbe. Uobičajene reproduktivne glazbene aktivnosti u vrtićkoj svakodnevnici su sve više spontano nadopunjavane spontanim stvaranjem novih i originalnih improvizacija kao temeljnog oblika glazbeno-stvaralačkih aktivnosti, što je, uz razvoj djetetovih stvaralačkih potencijala, osobito pozitivno utjecalo na razvoj njegova samopouzdanja i osjećaja vrijednosti. U početku su te improvizacije bile individualne, a kasnije su, međusobnim poticanjem djece, prerastale u zajedničke aktivnosti stvarajući tako kvalitetnu socijalnu interakciju koju je pratio osjećaj ushićenja i radosti.

Suradnja s roditeljima i širom zajednicom dodatno je doprinijela spoznaji o važnosti očuvanja i upotrebe različitih oblika tradicijske baštine, te njezinom širenju. Tijekom obogaćivanja odgojno-obrazovnih procesa elementima nematerijalne dječje tradicijske baštine, ustanovljeno je da djeca najveći interes i motivaciju pokazuju za brojalice i dječje igre s pjevanjem koje pružaju neiscrpan izvor glazbenih aktivnosti i doživljaja glazbe. Poticanjem dječjeg slobodnog stvaralačkog izraza putem improvizacije, djeca su na nov način doživjela izvođenje i pjevanje pjesmica za koje su ranije pokazivala manji interes, što su dodatno potvrdili rezultati provedene ankete. Provođenjem navedenih stvaralačkih aktivnosti, naglasak je stavljen na poticanje djetetove slobode izraza, stvaralačke mašte i emotivnog doživljaja, što je nadalje, uz bolje upoznavanja djeteta i otkrivanja njegovih skrivenih potencijala, dovelo do novih spoznaja vezanih uz dobrobit glazbenih i glazbeno-stvaralačkih aktivnosti na djetetov cjeloviti razvoj. Osobito je uočen značajan napredak kod djece s poteškoćama u razvoju, a to je osobit doprinos ovog istraživanja.

Dvostruko je značenje i doprinos ovog akcijskog istraživanja: upoznavanje različitih oblika tradicijskoga stvaralaštva i doprinos razvoju djetetovih stvaralačkih potencijala koje danas ima sve veće značenje s obzirom na zahtjeve koje suvremeno društvo postavlja pred čovjeka.

Osnovni smisao istraživanja nije dakle bio samo poticaj i nadahnuće djeci, već i odgojitelju i istraživaču na daljnju akciju u potrazi za otkrivanjem novih načina na koje će djeci približiti i uljepšati njihove glazbene aktivnosti. 


\section{Zaključno promišljanje}

Uz brojne dobrobiti glazbenih aktivnosti koje omogućuju razvoj djetetovih stvaralačkih potencijala i njegova cjelovitog razvoja, ovo istraživanje potvrdilo je važnost i vrijednost dječjeg tradicijskog naslijeđa koje također doprinosi obogaćivanju svakodnevnoga glazbenog doživljaja djece rane i predškolske dobi. U tom razdoblju, djeca najprije kao promatrači počinju upoznavati kulturu svojeg naroda, a zatim kao aktivni sudionici postaju dionici nacionalne predajne baštine. ${ }^{29}$ Promjene i obogaćivanje odgojno-obrazovnog procesa elementima tradicijskog stvaralaštva trebale bi biti početak dugotrajnog procesa, koji bi se trebao nastaviti tijekom djetetova daljnjeg razvoja. To je osobito važno s obzirom na osiromašenje senzibiliteta za zavičajnu i tradicijsku glazbu koje se sve više širi među mladima u urbanim sredinama. Glazba je proizvod svake kulture, a posebno je tradicijska glazba važna za očuvanje kulturne baštine i razvoj kulturnog identiteta, a u konačnici rađa nove oblike kulture u kombinaciji s tradicijom. ${ }^{30}$ Upravo vrtić kao predškolska institucija ima jednu od temeljnih misija u razvoju i očuvanju svijesti prema glazbenom tradicijskom blagu djeteta, budućeg kulturnog građanina.

Budući da je poticanje djetetove kreativnosti osnova njegova razvoja u inicijativnu i inovativnu osobu, važno je poticati je i razvijati različitim oblicima izražavanja i stvaranja tijekom odgojno-obrazovnoga procesa. Pri svemu tome, u svim stvaralačkim procesima, najvažniji je djetetov doživljaj. Emotivnim doživljajem glazbe, slobodnim izrazom, spontanošću, nesputanošću razvija se djetetova stvaralačka fantazija, koja čini osnovu, koliko za daljnje aktivnosti glazbenog stvaranja, toliko i za djetetov stvaralački razvoj u životu općenito.

\footnotetext{
${ }^{29}$ Usp. Knežević, Naše kolo veliko..., 8.

${ }^{30}$ Usp. Dijana DRANDIĆ, Tradicijska glazba u kontekstu interkulturalnih kompetencija učitelja, Pedagogijska istraživanja, 7 (2010) 1, 95-109.
} 


\section{Blaženka Bačlija Sušić ${ }^{*}$ - Nikolina Fišer ${ }^{* * *}$ \\ Musical enrichment children in early and preschool age with traditional creation}

\section{Summary}

The subject of this action research is musical encouragement and enrichment children in early and preschool age with traditional creation. The study deal with the question of possibility of improving the educational process with children in early and preschool age by encouraging and enriching musical experience with elements of traditional creativity.

The goal of this study was to find out which musical elements, contents and activities of children traditional creation are acceptable and interesting with three and four year old children and do they encourage them for the musical experience and interest in musical activities in general.

The study results show that children in early and preschool age show great interest in musical activities that include sounds exploration of different traditional instruments as well as for their use in musical performing. Everyday enrichment of educational process with traditional music through rhymes, children's songs and singing games by using traditional instruments, encourages child's freedom and spontaneity, creative imagination and creativity and enrich their emotional experience of music.

Key words: action research, music creation, music experience, early and preschool age children, traditional creation.

(na engl. prev. Božena Šimić)

\footnotetext{
* Blaženka Bačlija Sušić, PhD in music pedagogy, teacher in GU Elly Bašić, Address: Mlinarska c. 25, HR-10000 Zagreb, Croatia; E-Mail: blazenkabs@gmail.com.

**Nikolina Fišer, mag. praesc. educ., preschool educator in Kindergarten »Špansko«, Address: Špansko 11, HR-10000 Zagreb, Croatia; E-Mail: ninolina.f@gmail.com.
} 